\title{
Changes in oxygen saturation and heart frequency during sleep in young normal subjects
}

\author{
F GIMENO, R PESET
}

From the Pulmonary Function Laboratories Beatrixoord, Haren and University Hospital, Groningen, The Netherlands

ABSTRACT Changes in oxygen saturation and heart frequency were measured during sleep in a group of 21 normal subjects ( 9 women and 12 men) aged 19-25. At the time of the investigation all were non-smokers, they had no respiratory complaints, and indices of lung function (lung volumes, volume-pressure diagram, and diffusing capacity for carbon monoxide) were within normal limits. In contrast to published data, there were no major changes in oxygen saturation and no differences between men and women.

Major changes in oxygen saturation $\left(\mathrm{SaO}_{2}\right)$ have been reported in apparently normal people during sleep, with a mean maximum decrease in saturation of about $11 \% .^{1}$ These changes in $\mathrm{SaO}_{2}$ were found in men, but not in women, in a group of 49 people with ages varying from 24 to 62 years. Other workers have found that in normal people, with ages varying from 28 to 45 years, no changes in $\mathrm{SaO}_{2}$ occur during sleep. ${ }^{23}$

In these last two publications the age range is rather wide and the criteria of normality are not precisely defined. We decided to investigate the changes in $\mathrm{SaO}_{2}$ during sleep in a more homogeneous group of young normal women and men. To minimise the influence of age ${ }^{4}$ we investigated only people from 19 to 25 years of age.

\section{Methods}

Twenty one symptom free, non-smoking students, 12 men and nine women, who had previously been informed about the aim of the investigation, took part in the study. They were admitted to hospital at $9.00 \mathrm{pm}$. After physical examination they were connected to the equipment and they went to sleep until 7.30 am the next day. They slept in their usual position (supine or right or left lateral position, with one or two cushions) and did not take any sleeping tablet.

Address for reprint requests: Dr F Gimeno, Beatrixoord, Dilgtweg 5, Haren (Gn), The Netherlands 9751 .

Accepted 13 April 1984
The depth and quality of the sleep were recorded by the observers and classified in three categories: 1 (slept well and was awake less than three times during the whole night), 2 (awake three times or more), and 3 (was awake the whole night). Heart frequency was used as a very simple indicator of sleep. According to Khatri and Freis, " confirmation of sleep can be obtained when a decrease of heart frequency from "awake" values occurs.

Oxygen saturation was measured with the ear oximeter (Hewlett-Packard $47201 \mathrm{~A}$ ) and heart frequency was registered every 30 seconds on a recorder (Hewlett-Packard $7825 \mathrm{~B}$ ). To obtain a compact curve of the whole procedure a paper speed of $1 \mathrm{~cm} / \mathrm{h}$ was used.

During sleep artefacts due to movements and snoring were recorded. At the end of the sleeping period arterial blood was withdrawn. Then within seven days of the sleep study the volunteers underwent assessment of their lung function. A volumepressure diagram was constructed according to the technique of Hilvering, ${ }^{5}$ spirometry and measurement of residual volume were carried out according to the technique of Tammeling, ${ }^{6}$ and the single breath transfer factor for carbon monoxide was measured according to the technique of Peset and Gimeno. ${ }^{7}$ Reference values were those of Hilvering ${ }^{5}$ (lung mechanics), Tammeling ${ }^{8}$ (spirometric values and residual volume), and Cotes ${ }^{9}$ (transfer factor).

\section{Results}

Lung function and other biological data of the subjects taking part in this survey are summarised in 
Table 1 Mean (SD) values of some biometric and lung function data obtained in 21 young normal subjects

\begin{tabular}{lcc}
\hline & Women & Men \\
\hline Number & 9 & 12 \\
Age (years) & $21 \cdot 8(1 \cdot 9)$ & $22 \cdot 7(1 \cdot 9)$ \\
Weight (kg) & $63 \cdot 5(10 \cdot 0)$ & $78 \cdot 5(8 \cdot 2)$ \\
Height (cm) & $171 \cdot 0(8 \cdot 2)$ & $184 \cdot 8(5 \cdot 4)$ \\
$\mathrm{SaO}_{2}(\%)$ & $96 \cdot 8(0 \cdot 4)$ & $96 \cdot 8(0 \cdot 4)$ \\
$\mathrm{W}_{\mathrm{sp}, 1}(\mathrm{~J} / \mathrm{l})$ & $0 \cdot 09(0 \cdot 03)$ & $0 \cdot 10(0 \cdot 05)$ \\
$\mathrm{C}_{\text {St }}(\mathrm{V} / \mathrm{kPa})$ & $2 \cdot 00(0 \cdot 50)$ & $2 \cdot 40(0 \cdot 60)$ \\
TLC (\% predicted) & $96 \cdot 6(7 \cdot 9)$ & $99 \cdot 6(11 \cdot 0)$ \\
VC (\% predicted) & $100 \cdot 3(7 \cdot 9)$ & $106 \cdot 4(12 \cdot 1)$ \\
FEV (\% predicted) & $107 \cdot 4(9 \cdot 1)$ & $112 \cdot 6(12 \cdot 0)$ \\
Kco (\% predicted) & $94 \cdot 4(8 \cdot 2)$ & $102 \cdot 0(11 \cdot 7)$ \\
\hline
\end{tabular}

TLC - total lung capacity; VC-vital capacity; $\mathrm{W}_{\mathrm{sp}, 1}$-specific work of breathing; $\mathrm{C}_{\mathrm{st}, 1}$-static compliance of the lungs; SaO ${ }_{2}-$ arterial oxygen saturation calculated from the arterial oxygen tension $\left(\mathrm{PaO}_{2}\right)$ and the $\mathrm{pH} ; \mathrm{Kco}$-transfer coefficient (transfer factor for carbon monoxide divided by alveolar volume).

table 1 . They lie within twice the standard deviation of the predicted values used in our laboratories. ${ }^{58-10}$ Different types of movements and snoring were observed during sleep. These had no apparent influence on the measured values of $\mathrm{SaO}_{2}$ during sleep.

When the following morning the subjects were questioned about the quality of the sleep there were no large discrepancies between their answers and the observers' classifications. Sleep in nine subjects (six of them men) was classified as category 1 , in 12 subjects (four of them men) as category 2 , and in one woman as category 3 . This last was excluded from the study. In this study women seemed to have more difficulty in sleeping than men.

The values of $\mathrm{SaO}_{2}$ for the waking periods and during sleep are summarised in table 2 . The mean (SD) $\mathrm{SaO}_{2}$ value for women during the whole period was $96.9 \%(0.5 \%)$ and for men $97.3 \%(0.6 \%)$. This represents a mean difference of 0.4 , which is not significant.

The mean heart rate during the whole recording was $67 \cdot 8(9.9)$ per minute for women and $59.9(9.8)$ for men. This difference of 7.9 beats per minute is not statistically significant. The heart rate decreased by between 9 and 17 beats per minute below the rate recorded during the first hour of sleep. The largest differences were measured between 3 and 6 am, which according to Khatri and Freis is a sign of sleep.

\section{Discussion}

Our concept of normality is based on the following criteria: the subjects were non-smokers, they had no history of respiratory symptoms, they had normal findings on physical examination, and their lung function indices were greater than $80 \%$ of the predicted values. ${ }^{10}$

The strict criteria of normality used in the selection of our subjects could explain the discrepancy between our results and those of other investigators. Unlike Block et al ${ }^{1}$ we have been unable to find periods of hypoxaemia during sleep in our group of normal young subjects. Block's group of normal subjects had a mean age of 38 years for men and 29 for women, ranging from 20 to 62 years. The mean age of our group was 22 years (range 19-25 years). Furthermore, seven smokers were included in Block's group but none in our group.

Our results agree with those of Douglas $e t a l^{2}$ and Muller et $a l,{ }^{3}$ who did not find any hypoxaemia in respectively four and five young normal people. Although the depth of the sleep was not monitored by continuous recording of the electroencephalogram, it can be stated that the subjects slept almost the whole night on the basis of continuous observation of the subjects as well as the subjective assessment of the sleep made the next morning by the volunteers. The changes in heart frequency during the study can be considered as a confirmation of the

Table 2 Individual values of oxygen saturation (\%) awake and during sleep in nine normal women and 12 normal men (mean nocturnal oxygen saturation is the overall mean)

\begin{tabular}{|c|c|c|c|c|c|c|c|c|c|c|c|c|c|}
\hline MEN & 1 & 2 & 3 & 4 & 5 & 6 & 7 & 8 & 9 & 10 & 11 & 12 & Mean (SD) \\
\hline $\begin{array}{l}\text { Awake } \\
\text { Mean nocturnal } \\
\text { Lowest }\end{array}$ & $\begin{array}{l}97 \\
98 \\
96\end{array}$ & $\begin{array}{l}97 \\
98 \\
97 \cdot 5\end{array}$ & $\begin{array}{l}97 \\
97 \cdot 7 \\
96 \cdot 5\end{array}$ & $\begin{array}{l}97 \\
97 \cdot 5 \\
97\end{array}$ & $\begin{array}{l}97 \\
96 \cdot 8 \\
96 \cdot 0\end{array}$ & $\begin{array}{l}96 \cdot 5 \\
96 \cdot 6 \\
96\end{array}$ & $\begin{array}{l}96 \cdot 5 \\
96 \cdot 5 \\
95 \cdot 5\end{array}$ & $\begin{array}{l}96 \cdot 5 \\
96 \cdot 6 \\
96\end{array}$ & $\begin{array}{l}96 \cdot 5 \\
97 \cdot 8 \\
96\end{array}$ & $\begin{array}{l}96 \cdot 5 \\
97 \cdot 5 \\
97\end{array}$ & $\begin{array}{l}97 \\
97 \\
96\end{array}$ & $\begin{array}{l}96 \cdot 5 \\
97 \\
96 \cdot 5\end{array}$ & $\begin{array}{l}96.75(0.26) \\
97.25(0.56) \\
96.33(0.51)\end{array}$ \\
\hline WOMEN & 1 & 2 & 3 & 4 & 5 & 6 & 7 & 8 & 9 & Mean & $(S D)$ & & \\
\hline $\begin{array}{l}\text { Awake } \\
\text { Mean nocturnal } \\
\text { Lowest }\end{array}$ & $\begin{array}{l}96 \\
97 \\
96\end{array}$ & $\begin{array}{l}97 \\
96 \\
95 \cdot 5\end{array}$ & $\begin{array}{l}97 \\
96 \cdot 5 \\
95\end{array}$ & $\begin{array}{l}97 \\
97 \cdot 1 \\
95\end{array}$ & $\begin{array}{l}97 \\
97 \cdot 5 \\
97\end{array}$ & $\begin{array}{l}96 \cdot 5 \\
97 \cdot 3 \\
95\end{array}$ & $\begin{array}{l}96 \cdot 5 \\
97 \cdot 3 \\
96\end{array}$ & $\begin{array}{l}97 \\
96 \cdot 6 \\
95 \cdot 5\end{array}$ & $\begin{array}{l}96 \cdot 5 \\
96 \cdot 9 \\
95 \cdot 5\end{array}$ & $\begin{array}{l}96 \cdot 72 \\
96 \cdot 91 \\
95 \cdot 60\end{array}$ & $\begin{array}{l}(0.36) \\
(0.47) \\
(0.65)\end{array}$ & & \\
\hline
\end{tabular}


presence of sleep periods, which agreed with the subjective assessment of sleep. ${ }^{112}$ Despite the difference in depth of sleep between categories 1 and 2 we did not find differences in oxygen saturation between the two categories. The difference between men and women reported by Block et al ${ }^{1}$ is not reflected in our results. In men they found periods of hypoxaemia, defined as a $4 \%$ decrease in $\mathrm{SaO}_{2}$ from the preceding baseline, which did not occur in women. We found no significant differences in oxygen saturation between men and women. Muller et $a l^{3}$ similarly found no differences between three normal young women and two men.

The oxygen saturation of arterial blood during sleep in a group of 22 young people was fairly constant, varying from $95 \%$ to $99 \%$. No differences in saturation were found between men and women.

This work was supported by a research grant from the Netherlands Asthma Foundation. We thank Drs H Reinders-Folmer and R Verner for their technical assistance.

\section{References}

' Block AJ, Boysen PG, Wynne JW, Hunt LA. Sleep apnea, hypopnea and oxygen desaturation in normal subjects. A strong male predominance. $N$ Engl J Med 1979;300: 513-7.

${ }^{2}$ Douglas NJ, Calverley PMA, Leggett RJE, Brash HM,
Flenley DC, Brezinova V. Transient hypoxaemia during sleep in chronic bronchitis and emphysema. Lancet $1979 ; \mathrm{i}: 1-4$.

${ }^{3}$ Muller NL, Francis PW, Gurwitz D, Levison H, Bryan AC. Mechanism of hemoglobin desaturation during rapid-eye-movement sleep in normal subjects and in patients with cystic fibrosis. Am Rev Respir Dis 1980; 121:463-9.

${ }^{4}$ Sorbini CA, Grassi V, Solinas E, Muiesan G. Arterial oxygen tension in relation to age in healthy subjects. Respiration 1968;25:3-13.

${ }^{5}$ Hilvering C. Longmechanische onderzoekingen bij patienten met longtuberculose. MD thesis, Groningen University, 1963:33.

- Tammeling GJ. Het residuaal volume en de functionele residuaal capaciteit. MD thesis, Groningen University, 1958:38.

' Peset R, Gimeno F. Medida del factor de transferencia (capacidad de difusion pulmonar) con monoxido de carbono segun la tecnica de respiracion unica. Archivos de Bronconeumologia 1974; 10:6-9.

* Tammeling GJ. Standard values for lung volumes and ventilatory capacity of sanatorium patients. Selected papers of the Royal Netherlands Tuberculosis Society 1961;1:65-89.

${ }^{9}$ Cotes JE. Lung function: 3rd ed. Oxford: Blackwell Scientific Publications, 1975:384.

${ }^{10}$ Bruce JS, Peter GS. Per cent of predicted as the limit of normal in pulmonary function testing: a statistically valid approach. Thorax 1979;34:1-3.

${ }^{11}$ Khatri IM, Freis ED. Hemodynamic changes during sleep. J Appl Physiol 1967;22:867-73.

${ }^{12}$ Lugaresi E. Polygraphic aspects of sleep in man. Bull Europ Physiopath Respir 1972;8:1071-4. 